\title{
O CONTADOR E A TECNOLOGIA DA INFORMAÇÃO APLICADA À ESCRITURAÇÃO CONTÁBIL NA REGIÃO MÉDIO-NORTE MATOGROSSENSE
}

\author{
Silvana Machado Oliveira1, Paulo Cesar Souza ${ }^{2}$
}

\begin{abstract}
RESUMO
A T.I., em virtude da facilidade no acesso e redução dos custos de aquisição, tem sido amplamente utilizada na atuação do profissional contábil. Diante disso, esta pesquisa objetivou verificar, com base na opinião dos profissionais contábeis do município de Tangará da Serra, os impactos da tecnologia da informação aplicada à escrituração contábil na atuação dos contadores. A pesquisa teve a participação de 31 escritórios e profissionais contábeis, de um total de 38. Os resultados mostram que há utilização da Tecnologia da Informação pelos escritórios e profissionais contábeis, promovendo a agilidade do trabalho e reduzindo os riscos de fraude e demandando a requalificação dos profissionais. Percebe-se também a necessidade de conscientização dos empresários para a importância da adequação a essa nova realidade de modo a facilitar o trabalho do contador.
\end{abstract}

Palavras-Chave: Tecnologia da Informação. SPED. Profissão Contábil.

\section{ABSTRACT}

The T.I., because of ease of access and reduced acquisition costs, has been widely used in the accounting professional performance. Therefore, this study aimed to verify, based on the opinion of accounting professionals Tangara municipality of Serra, information technology impacts applied to bookkeeping in the performance of counters. The research was attended by 31 offices and accounting professionals, a total of 38 . The results show that there is use of information technology by offices and accounting professionals, promoting agility work and reducing the risk of fraud and demanding the rehabilitation of professionals. It also realizes the need for awareness of entrepreneurs of the importance of adaptation to this new reality in order to facilitate the work of the counter.

Keywords: Information Technology, SPED, Accounting Profession.

\section{INTRODUÇÃO}

Com a crescente evolução econômica, tecnológica e social da humanidade, a contabilidade é a ciência que nos auxilia não só no cumprimento das obrigações fiscais, mas também no registro, controle e administração do patrimônio das entidades. O contador é a figura essencial para transmitir informações confiáveis e que façam a diferença na administração da empresa e no processo de continuidade e crescimento da mesma. No entanto, assim como em outros setores, a tecnologia da informação tem sido uma grande aliada do profissional contábil, produzindo vários impactos na contabilidade e na atuação do profissional (CORDEIRO e DUARTE, 2006).

${ }^{1}$ Universidade do Estado de Mato Grosso

${ }^{2}$ Universidade do Estado de Mato Grosso, Secretaria de Estado de Saúde 
Silva e Kruger (2012) afirmam que os profissionais contábeis necessitam estar atentos às mudanças, pois se vivencia a era do conhecimento e da informática, o que exige muito do capital intelectual e a procura de profissionais cada vez mais preparados para atender as necessidades do fisco e do mercado. O profissional contábil, no desenvolvimento de suas funções, aplica conhecimentos específicos da ciência, da tecnologia e ainda apela para complementos de saber oriundos de disciplinas correlatas, como a administração, economia, direito e sociologia (SILVA e KRUGER, 2012).

A tecnologia da informação é hoje uma das ferramentas fundamentais para facilitar o processamento de dados contábeis, trazendo agilidade, confiabilidade e eficiência na prestação de serviços contábeis para o gerenciamento das atividades empresariais (SÁ, 2006).

Uma das formas de aplicação da tecnologia da informação na atividade contábil é o Sistema Público de Escrituração Digital (SPED). Mecanismo criado pelo governo a fim de integrar as entidades e contabilistas com o fisco com o intuito de facilitar a fiscalização quanto à comercialização de mercadorias e serviços, reduzindo a sonegação de impostos e possíveis fraudes contra o sistema. Com a utilização desse sistema, há maior preocupação quanto à transmissão de informações, pois, caso tais obrigações não sejam adequadamente cumpridas, há o risco de gerar ônus às empresas, seja pelo atraso ou erro no envio dos dados. Assim, as empresas e os profissionais da contabilidade precisam estar atentos na geração de informações corretas de modo a evitar equívocos entre as movimentações físcais e os registros contábeis (FORTES 2009).

Diante do exposto, este trabalho tem como ponto de partida a seguinte questão: Quais os impactos da utilização da tecnologia da informação aplicada à escrituração contábil na atuação dos profissionais contábeis do município de Tangará da serra - MT? A proposta é identificar a opinião dos profissionais a respeito dos impactos da tecnologia da informação aplicada à escrituração contábil na atuação dos contadores no município de Tangará da Serra, com intuito de analisar quais são as mudanças geradas pela aplicação crescente dessa tecnologia na escrituração contábil. Além disso, objetiva-se traçar o perfil dos profissionais e escritórios contábeis do município quanto aos aspectos gerais e quanto à utilização da tecnologia da informação e verificar também a opinião dos profissionais contábeis a respeito do comprometimento dos empresários em relação às novas exigências do governo quanto à utilização do SPED. 


\section{REFERENCIAL TEÓRICO}

\subsection{A Contabilidade e a Tecnologia da Informação}

A Tecnologia da Informação (TI) aplicada à contabilidade facilita a realização dos registros contábeis e o gerenciamento das atividades empresariais. O desenvolvimento tecnológico fez surgir inúmeras ferramentas que facilitam o trabalho do profissional contábil, trazendo mais rapidez e qualidade na geração de informações e tornando o processo de tomada de decisão mais ágil. Tais recursos tecnológicos ajudam a maximizar a principal função da contabilidade que é a produção de informação (MARTINS et. al, 2012).

Conforme Martins et al. (2012), a atuação do profissional contábil é um fator importante no processo de evolução da contabilidade e no crescimento das tecnologias relacionadas à área, pois à medida que ocorre o desenvolvimento da profissão e das exigências governamentais, maiores são os investimentos em recursos para facilitar as atividades e agregar valor à profissão

A profissão contábil passou por um momento de transição, em que a fase mecânica foi substituída pela técnica e, posteriormente, pela fase da informação. Desde então, dificilmente o contabilista conseguirá sobreviver no papel do antigo guarda-livros. Diante dessa nova realidade, o profissional contábil deve estar em constante evolução e qualificação, sendo assim um agente de mudanças no mercado, capaz de transmitir informações de qualidade que auxiliem no processo decisório das empresas (MARION, 2005).

Essa nova fase da contabilidade se apropriou da perspectiva sistêmica, fazendo surgir assim o chamado sistema de informação contábil. De acordo com Oliveira (2002, p.35), “um sistema é um conjunto de partes interagentes e interdependentes que, conjuntamente, formam um todo unitário com determinado objetivo e efetuam determinada função". Desse modo, são vários elementos interligados entre si, com objetivo de realizar determinada função.

Quanto aos tipos de sistemas Bazzotti e Garcia (2006), afirmam que são classificados de acordo com sua utilização e o retorno obtido no processo de tomada de decisões, classificando-se assim em sistemas de apoio às operações e sistemas de apoio gerencial. Os sistemas de apoio às operações têm por função controlar atividades, processos e atualizar banco de dados para assim fornecer as informações necessárias. Os sistemas de apoio gerencial têm a finalidade principal de fornecer informações para o processo de tomada de decisões (BAZZOTTI e GARCIA, 2006).

Dentre os sistemas gerenciais e de apoio as operações, tem-se os sistemas de informação contábil que são definidos por Padoveze (2004, p. 143) como “os meios que o 
contador geral, o contador gerencial ou o controller utilizarão para efetivar a contabilidade e a informação contábil dentro da organização, para que a contabilidade seja utilizada em toda a sua plenitude". Para Gil (1999, p.23) os sistemas de informação contábil são “o conjunto de recursos humanos e de capital dentro da organização o qual é responsável pela preparação de informações financeiras e também das informações obtidas da coleta e processamento dos dados das transações".

De acordo com Padoveze (2010), o sistema de informação contábil classifica-se no grupo dos sistemas de apoio à gestão. Os sistemas que se enquadram nessa classificação ocupam-se basicamente com as informações necessárias à gestão econômico-financeira da empresa. Os sistemas de informação contábil atualmente são operacionalizados utilizando a Tecnologia da Informação. De acordo com Bazzotti e Garcia (2006) o sucesso das empresas está ligado à velocidade com que as informações são assimiladas e pela rapidez no processo de tomada de decisões e a tecnologia da informação é a principal ferramenta para que isto ocorra.

Padoveze (2009) conceitua a tecnologia da informação como um conjunto tecnológico a disposição das empresas para efetivar seu sistema de informação e suas operações, ressaltando que este conjunto está relacionado à informática e a telecomunicação, bem como ao desenvolvimento cientifico do processo de transmissão de dados. Para Cruz (2000, p.24) a "tecnologia da informação é todo e qualquer dispositivo que tenha capacidade para tratar dados e ou informações, tanto de forma sistêmica como esporádica, quer esteja aplicada no produto, quer esteja aplicada no processo".

Bazzotti e Garcia (2006) evidenciam ainda que a TI age, como uma intermediadora na geração e transmissão de informações para assim fazer com que os sistemas gerenciais funcionem da melhor forma possível no processamento e elaboração de dados para atingir o objetivo principal.

Através do avanço da tecnologia da informação os sistemas de informação contábil, se tornaram essenciais em qualquer tipo de atividade empresarial. Estes propiciam a geração de relatórios com informações contábeis e financeiras relevantes que contribuem para a gestão e utilização eficiente dos recursos e para a manutenção do equilíbrio financeiro da empresa, orientando administradores no processo de tomada de decisões mais convenientes e adequados e possibilitando o crescimento e a prosperidade da empresa (SOUZA; PASSALONGO, 2005). 
Para que um sistema de informação contábil seja útil, é necessário atender a empresa como um todo, levando informações a todos os setores e interligando todos os processos da empresa. O avanço tecnológico vem aumentando as oportunidades da utilização da contabilidade, pois através dele é possível obter informações em tempo real sobre todos os setores, atividades e funcionários relacionados à administração da empresa (COTRIN; SANTOS; JUNÍOR, 2012). Para que isso seja possível, a tecnologia da informação torna-se fator essencial, para a atividade do profissional contábil.

No processo de realização dos registros, Padoveze (2000) classifica os sistemas contábeis em: a) Manuais - utiliza livros ou fichas a para a escrituração; b) Mecanizados utiliza a máquina de datilografia, a máquina de soma e um formulário denominado "Ficha Tríplice"; e c) Eletrônico - utiliza o computador e demais equipamentos eletrônicos processando dados a partir de programas específicos.

Os sistemas manuais e mecanizados hoje praticamente não são utilizados, visto que a tecnologia da informação trouxe inovações que os substituem, como os computadores, internet, softwares e demais sistemas de escrituração contábil que são muito mais vantajosos pela praticidade, segurança e qualidade do serviço contábil (PADOVEZE, 2000). Diante dessa nova realidade, Cornachione Jr. (2001, p.105) diz que "hoje não é mais possível aceitar o eficaz desempenho profissionais em um amplo leque de atividades econômicas, científicas e educacionais e mesmo esportivas, sem o apoio da informática, a contabilidade não foge a regra". Sendo assim cabe aos profissionais atuantes no mercado buscar a cada dia uma qualificação, atualização e informações quanto aos recursos tecnológicos oferecidos pelo mercado a fim de garantir a qualidade da prestação de serviços e a valorização no mercado.

\subsection{Escrituração Contábil Digital}

A crescente evolução tecnológica e social advinda da globalização impactou diretamente na contabilidade, que vem passando por um processo de mudanças quanto à forma de contabilização e escrituração de suas atividades "historicamente a contabilidade passou de processos realizados manualmente para o que se chama hoje de padronização das informações" (RUSCHEL; FREZZA; UTZIG, 2011, p 10). Aproveitando-se dessa evolução, o governo, com o intuito de impedir fraudes, sonegação de impostos e a omissão de informações instituiu o SPED. Para especialistas, é uma revolução para a contabilidade brasileira e veio trazer inúmeros benefícios para ambas as partes quanto às operações (OLIVEIRA; PRADO; MORAES, 2012). 
O SPED foi instituído pelo Decreto $\mathrm{n}^{\circ}$ 6.022, de 22 de janeiro de 2007 (BRASIL, 2007) e faz parte do programa de Aceleração do Crescimento do Governo Federal (PAC 2007-2010), que o conceitua em seu artigo $2^{\circ}$ como:

\footnotetext{
Instrumento que unifica as atividades de recepção, validação, armazenamento e autenticação de livros e documentos que integram a escrituração comercial e fiscal dos empresários e das pessoas jurídicas, inclusive imunes ou isentas, mediante fluxo único, computadorizado, de informações.
}

A Receita Federal apresenta o sistema como uma modernização sistemática no cumprimento de obrigações acessórias, pois utiliza a certificação digital para fins de assinatura dos documentos eletrônicos gerados. Os principais objetivos do sistema são: promover a integração dos fiscos, racionalizar e uniformizar as obrigações acessórias para os contribuintes, permitir melhorias no controle dos processos com rapidez no acesso a informações e fiscalização de operações com cruzamento de dados (BRASIL, 2007).

De acordo com Manoel et al. (2011), dentre os benefícios tem-se também a preservação do meio ambiente, pela economia de papel, a redução de tempo utilizado para fazer os registros contábeis, maior facilidade no controle de informações e também o fortalecimento do controle das informações. Em suma, o SPED nada mais é que um software desenvolvido por meio do qual o contribuinte deve transmitir suas informações ao fisco e que traz consigo todos esses benefícios.

Além de ser um instrumento do governo para controle do recolhimento adequado dos tributos, Duarte (2011) atribui ao SPED função de ferramenta de gestão.

Segundo o autor, esse sistema pode ser eficaz no controle dos tributos e no gerenciamento das atividades empresariais, que permite uma visão global do negócio combinada a uma atuação integrada. 
Figura 1 - Diretrizes do gestor eficaz

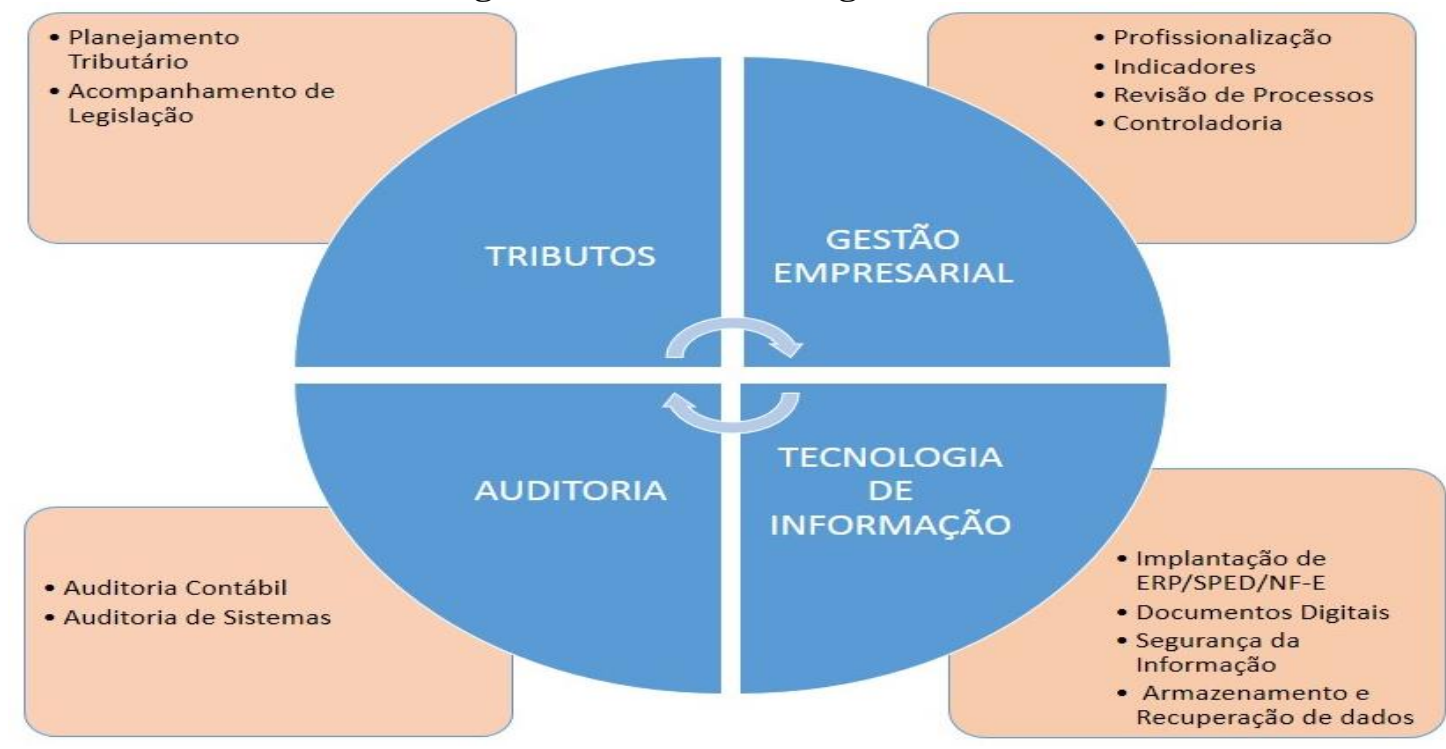

Fonte: Duarte (2011)

É importante ressaltar que o SPED é um grande projeto do governo, o qual tem dentro de sua área de atuação, vários outros subprojetos, os quais são: SPED Fiscal, SPED Contábil, Nota fiscal eletrônica (NF-e), Escrituração Contábil Digital (ECD), entre outros. Através da implementação do SPED fiscal em conjunto com o SPED contábil, as empresas passaram a ser desobrigadas da apresentação da maioria das informações e documentações antes exigidas impressas, facilitando assim também a fiscalização, recepção e o processamento das informações (OLIVEIRA et al., 2014).

O SPED gera para as empresas uma maior exposição, já que o fisco acompanha em tempo real as transações empresariais, além disso, gera uma padronização em virtude da integração dos dados entre a receita federal e as secretarias de fazenda (OLIVEIRA, et al., 2014).

Os diversos subprojetos do SPED são apresentados a seguir na figura 2, elaborada com base em Brasil (2015). 
Figura 2 - Subprojetos do SPED

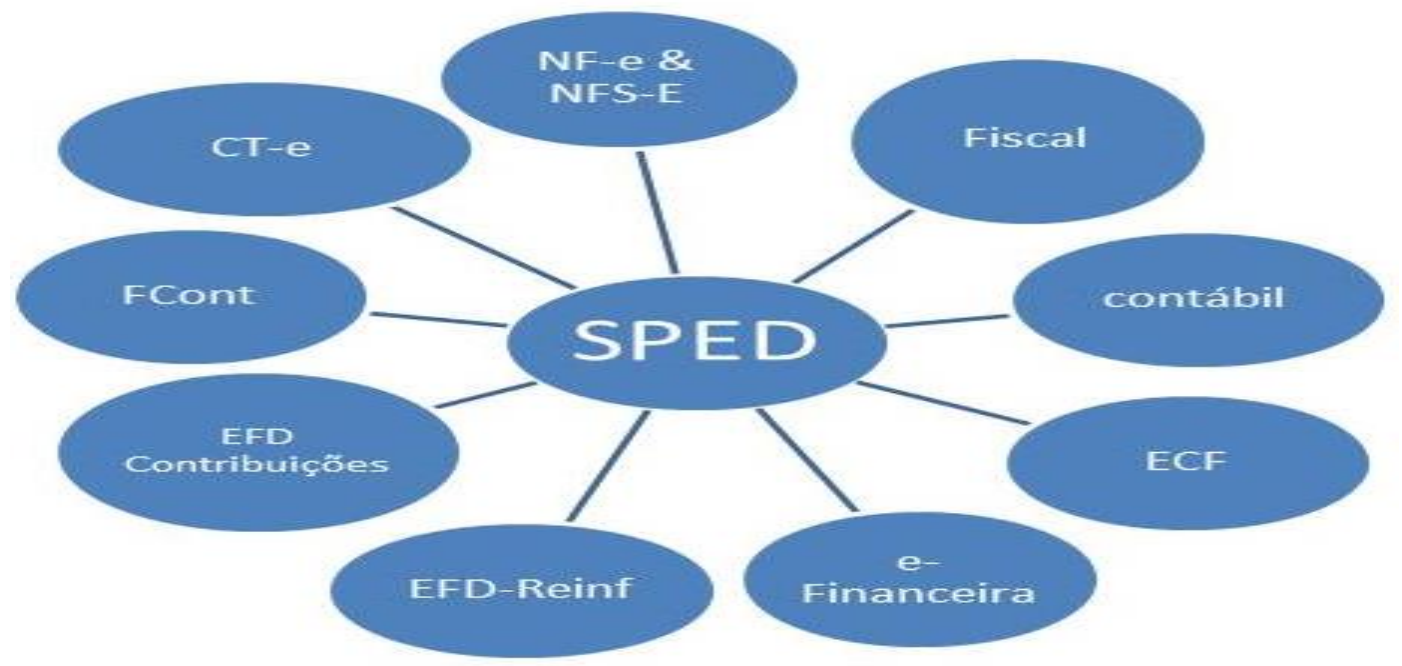

Fonte: Elaborado com base em Brasil (2015)

O SPED contábil é, na prática, a mesma escrituração contábil digital apresentada a seguir. O SPED fiscal é um arquivo também digital, que é formado por um conjunto de escriturações de documentos fiscais e de outras informações de interesse dos fiscos das unidades federadas e da Secretaria da Receita Federal do Brasil, e dos registros de apuração de impostos referentes às operações e prestações praticadas pelas empresas. Ele funciona a partir de sua base de dados, onde a empresa gera um arquivo digital de acordo com layout estabelecido, informando todos os documentos fiscais e outras informações de interesse dos fiscos federal e estadual, referentes ao período de apuração dos impostos ICMS e IPI. Esse arquivo deverá ser submetido à importação e validação pelo Programa Validador e Assinador (PVA) fornecido pelo SPED (BRASIL, 2015).

A Escrituração Contábil Digital (ECD) visa substituir a escrituração e transmissão antes feita em papel impresso, por arquivos digitais. De acordo com a Instrução Normativa RFB N 1420, de 19 de Dezembro de 2013 em seu artigo $2^{\circ}$ a ECD corresponderá às versões digitais dos seguintes livros:

I - Livro Diário e seus auxiliares se houver;

II- Livro Razão e seus auxiliares se houver

III- Livro Balancetes Diários Balanços e fichas de lançamento comprobatórias dos assentamentos neles transcritos; (BRASIL, 2015). 
A ECD deve ser registrada na junta comercial do estado, por meio do arquivo validador em um programa próprio. Devem conter assinatura digital do representante da empresa na Receita Federal e também do contabilista responsável (MANOEL et al., 2011).

Além de substituir os principais livros, a ECD também objetiva substituir obrigações acessórias. Assim, a ECD é um arquivo texto que em conjunto com a EFD (Escrituração Fiscal Digital), objetiva substituir a escrituração contábil física e as obrigações acessórias, as quais são: DIPJ, DIRF, DCTF, DACON (MANOEL, et al., 2011).

A ECD é composta por termo de abertura e encerramento, livro diário, livro razão, balanço patrimonial, demonstração do resultado do exercício e os demais itens que sejam obrigatórias para a empresa. O programa validador utilizado atualmente é o PVA (Programa Validador Assinador) que é disponibilizado no site da receita federal para fins de validação dos arquivos gerados, bem como assinatura digital e transmissão para o SPED (BRASIL, 2012).

Neste contexto, a ECD visa facilitar o processo de escrituração contábil, bem como tornar as informações mais seguras. Inicialmente a obrigatoriedade da entrega da ECD era para empresas sujeitas a tributação pelo lucro real, porém a Instrução Normativa $R B F n^{\circ}$ 1.420, de 19 de dezembro de 2013 (BRASIL, 2015) estabeleceu novas regras sobre a ECD. Em seu artigo $3^{\circ}$ a Instrução Normativa versa que ficam obrigadas a adotar a ECD, nos termos do art. $2^{\circ}$ do Decreto $n^{\circ}$ 6.022.de 2007, em relação aos fatos contábeis ocorridos a partir de $1^{\circ}$ de janeiro de 2014 as seguintes empresas:

I - as pessoas jurídicas sujeitas à tributação do imposto sobre a Renda com base no lucro real;

II- as pessoas jurídicas tributadas com base no lucro presumido, que distribuírem, a título de lucros, sem incidência do Imposto sobre a Renda Retido na Fonte (IRRF), dos lucros ou dividendos superior ao valor da base de cálculo do imposto, diminuída de todos os impostos e contribuições que estiver sujeita; e

III- as pessoas jurídicas imunes e isentas;

Enquadram se em empresas jurídicas imunes as instituições de educação e assistência social, partidos políticos, sindicatos de trabalhadores e as igrejas. As empresas jurídicas classificadas como isentas são as instituições culturais, científicas, filantrópicas e entidades abertas de previdência complementar sem fins lucrativos.

Diante dessas inúmeras ferramentas do governo que buscam integrar-se ao contribuinte em tempo real a fim de evitar possíveis fraudes, é essencial que os profissionais 
contábeis estejam atentos quanto ao funcionamento desses sistemas. O domínio dessa tecnologia irá evitar erros quanto ao preenchimento das informações e também nas transmissões para o governo, o qual pode a qualquer momento verificar quanto à sua veracidade (BRASIL, 2007).

\section{METODOLOGIA}

O primeiro passo para a realização desta pesquisa foi a busca das referências bibliográficas em artigos científicos, livros, revistas, internet e demais publicações do que já havia escrito a respeito do assunto. Quanto à sua natureza esta pesquisa classifica-se como aplicada, pois tem o objetivo de gerar conhecimentos que contribuam com a profissão contábil. A abordagem na análise dos dados é quantitativa, sendo os mesmos apresentados por meio de estatística descritiva simples. Quanto aos seus objetivos, caracteriza-se uma pesquisa descritiva, pois através dela é possível descrever a evolução da ciência contábil, assim como a influência da tecnologia da informação para na profissão contábil. De acordo com Andrade (2002 apud BEUREN, 2003), a pesquisa descritiva é aquela em que os fatos são observados, registrados, analisados interpretados e descritos sem a interferência do pesquisador nos dados coletados.

A pesquisa foi realizada no município de Tangará da Serra, Mato Grosso, cidade localizada na região sudoeste mato-grossense a $250 \mathrm{~km}$ da capital do estado. O município possui uma população estimada em 92.298 pessoas (IBGE, 2014) e um total de 2.948 empresas cadastradas. A coleta dos dados desta pesquisa foi realizada tendo como alvo $100 \%$ dos profissionais autônomos e escritórios contábeis cadastrados junto à secretaria de fazenda do município de Tangará da Serra (SEFAZ), os quais totalizavam de acordo com o sistema do órgão 41 profissionais. No momento da pesquisa, verificou-se que três deles era inexistente, restando apenas 38 a serem pesquisados. Ressalta-se que em virtude da pesquisa haver sido realizada com profissionais autônomos e escritórios contábeis, de agora em diante, ao se referir aos pesquisados será utilizada a expressão escritórios/profissionais contábeis.

Como instrumento de coleta de dados foi utilizado um questionário elaborado com base nos trabalhos de Silva e Kruguer (2012) e Silva (2008). O questionário contém 21 questões distribuídas em três grupos: perfil dos profissionais ou escritórios de contabilidade, investimentos em tecnologia da informação e aplicação da tecnologia da informação na escrituração contábil e no trabalho do contador. As questões foram elaboradas em forma de questionário semi-estruturado e perguntas abertas (MANZATO e SANTOS, 2012), pois em 
alguns casos, foi colocada a possibilidade do respondente não marcar nenhuma das opções indicadas e adicionar uma nova opção de resposta.

A coleta de dados foi realizada durante o mês de julho de 2015, com a participação voluntária de 31 (81,58\%) do total de 38 escritórios/profissionais contábeis identificados.

Para o processamento dos dados foi utilizado o software Microsoft Excel, possibilitando a apresentação dos mesmos em tabelas e gráficos. Os dados foram analisados utilizando-se de estatística descritiva e comparados com outros estudos correlatos.

\section{RESULTADOS E DISCUSSÃO}

A seguir são apresentados os resultados da pesquisa, obtidos mediante a aplicação do questionário junto ao grupo de escritórios/profissionais que concordaram com a participação na pesquisa (31).

Inicialmente, apresenta-se o perfil dos escritórios/profissionais contábeis. As tabelas 1 a 4 mostram o resultado da aplicação das perguntas utilizadas, as quais se referem aos seguintes aspectos: gênero, número de funcionários, área de formação, forma jurídica de atuação no mercado, segmento de atuação de clientes e serviços contábeis prestados pelos escritórios. A tabela 1 demonstra o resultado dos dois primeiros aspectos, ou seja, gênero e área de formação dos profissionais envolvidos.

Quanto ao gênero, observou-se que 55,26\% dos profissionais são do sexo feminino e $26,32 \%$ do sexo masculino, ficando sem resposta 18,42\%. Se considerados apenas os respondentes, a diferença entre o sexo masculino $(32,26 \%)$ e o feminino fica ainda mais expressiva (67,74\%). Assim, ficou evidente que entre os escritórios/profissionais contábeis pesquisados há predominância de profissionais do sexo feminino.

Ao tratar do gênero na profissão contábil, Oliveira (2015) afirma que a profissão segue promissora para as mulheres uma vez que estas representam atualmente $42 \%$ dos profissionais registrados no Conselho Federal de Contabilidade (CFC). Desse modo, percebe-se que a composição dos profissionais quanto ao gênero, segue a tendência nacional de predominância do sexo feminino na profissão contábil, embora em torno de $24 \%$ dos profissionais que trabalham nos escritórios de contabilidade não tenham formação contábil.

Em relação à formação dos profissionais que atuam junto aos escritórios/profissionais contábeis, é importante ressaltar inicialmente que dentre os trinta e um questionários aplicados apenas em dezesseis foram obtidos respostas a esta pergunta. Assim, os dados 
apresentados abaixo se referem apenas aos profissionais que trabalham em 16 do total de 38 escritórios/profissionais existentes.

Dentre os que responderam à pesquisa, apenas 1,32\% possuem mestrado e 10,53\% especialização. Os demais números que se destacam são os profissionais graduados em ciências contábeis, os quais totalizam 38,82\% dos respondentes, os que possuem outro ensino médio $(20,39 \%)$, percentual bem acima dos técnicos em contabilidade existentes $(5,92 \%)$, e os que estão cursando ciências contábeis $(17,76 \%)$.

Tabela 1. Perfil dos profissionais que trabalham junto aos escritórios/profissionais contábeis, Tangará da Serra, 2015.

\begin{tabular}{l|cc}
\hline Variáveis & $\mathbf{N}^{\mathbf{0}}$ & $\mathbf{\%}$ \\
\hline Sexo & 10 & 26,32 \\
Masculino & 21 & 55,26 \\
Feminino & 7 & 18,42 \\
Sem resposta & & \\
Área de Formação & 0 & 0,00 \\
Pós Doutorado & 0 & 0,00 \\
Doutorado & 1 & 1,32 \\
Mestrado & 16 & 10,53 \\
Pós Graduado & 59 & 38,82 \\
Bacharel em Ciências Contábeis & 6 & 3,95 \\
Outra Graduação & 9 & 5,92 \\
Técnico em Contabilidade & 31 & 20,39 \\
Outro ensino Médio & 2 & 1,32 \\
Estagiários & 27 & 17,75 \\
Cursando Ciências Contábeis &
\end{tabular}

Fonte: Dados da Pesquisa (2015)

Percebeu-se um pequeno número de profissionais com outra graduação $(3,95 \%)$ e número bastante insipiente de estagiário $(1,32 \%)$. Quanto aos estagiários, uma atuação mais dinâmica da universidade junto aos escritórios/profissionais contábeis poderia abrir espaço para maiores contratações nesse sentido, contribuindo assim com a formação de mais acadêmicos. Também é importante destacar que é possível que o pequeno número desses profissionais seja em virtude de muitos dos acadêmicos de ciências contábeis já trabalharem como funcionários dos escritórios/profissionais pesquisados, visto que os acadêmicos de contábeis representam $18 \%$ dos respondentes.

Ainda tratando do perfil dos escritórios/profissionais contábeis, a tabela 2 mostra que quanto ao número de funcionários, há uma concentração dos números nas faixas que compreendem o quantitativo de 1 a 15 funcionários, as quais juntas totalizam 71,05\%, 
distribuídos em 31,58\% para a faixa de 1 a 5, 15,79\% para a faixa de 6 a 10 e 23,68\% para a faixa de 11 a 15 . Dentre estas faixas, destacou-se a primeira com o maior percentual. Os escritórios/profissionais que não possuem funcionário ou que possuem acima de 15 apresentaram o mesmo percentual $(5,26 \%)$ e os que não responderam foram $18,42 \%$.

Assim, com base nestes dados, pode-se afirmar entre os escritórios contábeis de Tangará da Serra predomina o número daqueles que tem um quadro funcional composto por no máximo quinze funcionários. Se considerados apenas os respondentes, esse percentual salta de $71,05 \%$ para $87,09 \%$.

Tabela 2. Número de funcionários dos escritórios/profissionais contábeis, Tangará da Serra, 2015.

\begin{tabular}{l|cc}
\hline Variáveis & $\mathbf{N}^{\mathbf{0}}$ & $\mathbf{\%}$ \\
\hline Não Possui & 2 & $5,26 \%$ \\
De 1 á 5 & 12 & $31,58 \%$ \\
De 6 a 10 & 6 & $15,79 \%$ \\
De 11 a 15 & 9 & $23,68 \%$ \\
Mais de 15 & 2 & $5,26 \%$ \\
Sem resposta & 7 & $18,42 \%$ \\
\hline
\end{tabular}

Fonte: dados da Pesquisa (2015)

A Tabela 3 mostra que dentre os pesquisados, a grande maioria atua como pessoa jurídica $(71,05 \%)$ e apenas $10,53 \%$ como pessoa física. Convém destacar que isso ocorre em função da existência de profissionais que, mesmo com estabelecimento contábil em funcionamento, atuavam como pessoa física e não como pessoa jurídica. Esta prática é legal e possível, visto que o profissional contábil tem profissão regulamentada e pode prestar seus serviços como autônomo exercendo, por exemplo, a função de consultor, auditor, perito e etc. Ressalta-se que, se forem considerados apenas os respondentes, o percentual daqueles que atuam com pessoa jurídica sobe para 87,09\%. A opção da maioria pela atuação como pessoa jurídica pode estar relacionada aos possíveis benefícios fiscais obtidos.

Em relação tempo de atuação no mercado, percebe-se uma concentração dos percentuais em quatro faixas principais. As faixas de 0 a 5 anos $(13,16 \%)$ e de 6 a 10 anos $(21,05 \%)$ concentram 34,21\% dos escritórios/profissionais, em seguida, as faixas de 16 a 20 anos $(13,16 \%)$ e acima de 21 anos $(26,32 \%)$ concentram um percentual ainda maior, ou seja, $39,48 \%$. Fica evidente que os escritórios/profissionais de contabilidade pesquisados estão concentrados nos dois extremos. Há um bom número de novos escritórios/profissionais, 
demonstrando o crescimento da profissão, mas também há um número ainda maior com mais de 15 anos de atuação. Se considerados apenas os respondentes, aqueles que tem até 10 anos de atuação representariam 41,93\% e aqueles com mais de 15 anos de atuação 48,38\% do total.

Na pesquisa de Silva (2008), realizada com 82 escritórios de contabilidade do Rio de Janeiro, também se percebe alta concentração na faixa com mais de 15 anos (54\%), bem semelhante aos dados encontrados aqui. Na faixa inicial, até 10 anos, os dados de Silva (2008) apresentam números menores $(28 \%)$.

Entre os escritórios/profissionais pesquisados, o segmento de atuação predominante foi o comércio $(31,18 \%)$, seguido pelo setor de serviços $(27,96 \%)$, indústrias $(17,20 \%)$ e entidades sem fins lucrativos $(16,13 \%)$. Estes dados diferem um pouco do perfil sócio econômico do município levantado pelo Núcleo de Ensino e Pesquisa em Contabilidade (NEPEC, 2011/12), onde o setor de serviços predominava (55,2\%), seguido do comércio $(33,2 \%)$ e da indústria (5,2\%). Ressalta-se que esta pesquisa não abrange todas as empresas do município, visto que sete (7) do total de 38 escritórios não participaram da pesquisa e não se sabe quantas empresas os mesmos atendiam, e ainda que todos participassem, muitas empresas possuem contabilidade própria e não estariam inclusos ainda assim na pesquisa.

Tabela 3. Perfil dos escritórios/profissionais contábeis, Tangará da Serra, 2015.

\begin{tabular}{l|cc}
\hline \multicolumn{1}{c}{ Variáveis } & $\mathbf{N}^{\mathbf{0}}$ & $\%$ \\
\hline Forma de Atuação & 27 & 71,05 \\
Pessoa Jurídica & 4 & 10,53 \\
Pessoa Física & 7 & 18,42 \\
Sem resposta & & \\
Tempo de Atuação no Mercado & 5 & 13,16 \\
Até 5 anos & 8 & 21,05 \\
De 6 a 10 anos & 3 & 7,89 \\
De 11 a 15 anos & 5 & 13,16 \\
De 16 a 20 anos & 10 & 26,32 \\
Acima de 21 anos & 7 & 18,42 \\
Sem resposta & & \\
Segmento de atuação dos Clientes & 26 & 27,96 \\
Setor de Serviços & 29 & 31,18 \\
Setor de comércio & 16 & 17,20 \\
Setor de Indústrias & 15 & 16,13 \\
Entidades sem Fins Lucrativos & 0 & 0,00 \\
Setor Financeiro & 7 & 7,53 \\
Outros & &
\end{tabular}

Fonte: dados da pesquisa (2015) 
Em relação aos serviços contábeis prestados pelos escritórios/profissionais (tabela 4), destacam-se escrita fiscal e folha de pagamento, ambas com 81,57\%, seguidos da escrita contábil com 76,31\%. Segundo os dados, esses três são os serviços mais comuns, com participação percentual com variações muito pequenas, ou seja, valores muito próximos.

Os serviços de consultoria $(34,21 \%)$, auditoria $(13,15 \%)$ e perícia contábil $(5,26 \%)$ ainda tem pouca expressividade entre os pesquisados. Talvez haja aí um mercado a ser mais explorado pelos profissionais contábeis.

Tabela 4. Serviços prestados pelos escritórios/profissionais contábeis, Tangará da Serra, 2015.

\begin{tabular}{l|cc}
\hline Variáveis & $\mathbf{N}^{\mathbf{o}}$ & $\mathbf{\%}$ \\
\hline Escrita Contábil & 29 & 76,31 \\
Escrita Fiscal & 31 & 81,57 \\
Folha de pagamento & 31 & 81,57 \\
Consultoria & 13 & 34,21 \\
Pericia Contábil & 2 & 5,26 \\
Auditoria & 5 & 13,15 \\
Não Responderam & 7 & 18,42 \\
\hline
\end{tabular}

Fonte: Dados da Pesquisa (2015)

A seguir, serão apresentados os resultados relacionados ao foco principal deste trabalho, ou seja, a tecnologia da informação aplicada à escrituração contábil.

A tabela 5 mostra que, dentre os 38 questionários aplicados, 81,58\% afirmaram utilizar software contábil em suas atividades, ou seja, todos os escritórios/profissionais que responderam ao questionário utilizam sistemas informatizados no desenvolvimento de suas atividades. Os dados mostram a importância da Tecnologia da Informação no trabalho do contador, ou seja, praticamente não se admite mais o trabalho de forma somente manual ou mecanizada.

Tabela 5. Utilização de software contábil pelos escritórios/profissionais contábeis, Tangará da Serra, 2015.

\begin{tabular}{l|cc}
\hline Variáveis & $\mathbf{N}^{\mathbf{0}}$ & $\mathbf{\%}$ \\
\hline Sim & 31 & $81,58 \%$ \\
Não & 0 & $0,00 \%$ \\
Não Responderam & 7 & $18,42 \%$ \\
\hline
\end{tabular}

Fonte: Dados da Pesquisa (2015) 
Quanto ao tempo de utilização de tais softwares (tabela 6), somente 34,21\% afirmaram utilizar o mesmo software há mais de 10 anos e o restante $(47,37 \%)$ tem até dez anos de utilização. Se considerados apenas os respondentes, aqueles que utilizam a mais de 10 anos somam 41,93\%. Percebe-se que, possivelmente pela maior facilidade no acesso aos sistemas informatizados nos últimos anos, bem como a redução nos custos do investimento, a maioria $(58,07 \%)$ dos respondentes utilizam os softwares contábeis a menos de 10 anos. Assim, a utilização em massa é relativamente recente.

Tabela 6. Tempo de Utilização do Software Contábil, Tangará da Serra, 2015.

\begin{tabular}{l|cc}
\hline Variáveis & $\mathbf{N}^{\mathbf{0}}$ & \% \\
\hline 1 ano & 2 & $5,26 \%$ \\
2 a 5 anos & 6 & $15,79 \%$ \\
6 a 10 anos & 10 & $26,32 \%$ \\
Mais de 10 anos & 13 & $34,21 \%$ \\
Não responderam & 7 & $18,42 \%$ \\
\hline \multicolumn{2}{l}{ Fonte: Dados da Pesquisa (2015) }
\end{tabular}

Fonte: Dados da Pesquisa (2015)

Em relação à quantidade de computadores existentes nos escritórios/profissionais contábeis (tabela 7), os dados se concentraram nas faixas entre 01 e 20 computadores, as quais somam 76,31\% do total e 93,54\% dos respondentes. Esse número de computadores está relacionado também ao porte dos escritórios/profissionais e ao quantitativo de pessoal existente. Ressalta-se que mesmo a tecnologia da informação e os sistemas contábeis sendo fundamental nas atividades do contador, o grau de investimento nestes recursos ainda são reduzidos. A pesquisa apontou que apenas 5,26\% das empresas pesquisadas investem acima de $20 \%$ do seu faturamento anual em informática e tecnologia. A grande maioria $(76,32 \%)$ investe até $15 \%$ do faturamento anual neste item conforme tabela 7.

Os sistemas de informações contábeis são importantes principalmente por agregar valor à empresa, disponibilizando informações exatas e acessíveis a qualquer momento, aumentando a eficiência e a eficácia e contribuindo no processo de tomada de decisão (SOUZA e PASSOLONGO, 2005). Assim, na atuação do contador não seria diferente, a aplicação da tecnologia da informação agiliza os processos, disponibilizando mais rapidamente as informações necessárias. 
Tabela 7. Quantidade de Computadores e Investimentos em TI, Tangará da Serra, 2015.

\begin{tabular}{l|cc}
\hline Variáveis & $\mathbf{N}^{\mathbf{0}}$ & $\mathbf{\%}$ \\
\hline Quantidade de computadores & & \\
Até 5 computadores & 13 & $34,21 \%$ \\
De 06 a 10 computadores & 7 & $18,42 \%$ \\
De 11 a 20 computadores & 9 & $23,68 \%$ \\
Mais de 20 computadores & 2 & $5,26 \%$ \\
Não responderam & 7 & $18,42 \%$ \\
Investimentos em TI & & \\
Até 5\% do faturamento anual & 10 & $26,32 \%$ \\
De 6 a 10\% do faturamento anual & 9 & $23,68 \%$ \\
De 11 a 15\% do faturamento anual & 10 & $26,32 \%$ \\
De 16 a 20\% do faturamento anual & 0 & $0,00 \%$ \\
Acima de 20\% do faturamento anual & 2 & $5,26 \%$ \\
Não Responderam & 7 & $18,42 \%$ \\
\hline Fonte: Dados da Pesquisa (2015) & &
\end{tabular}

A seguir são apresentados os resultados que demonstram a opinião dos contadores quanto à utilização da tecnologia da informação em sua atuação.

Como evidencia o gráfico 1, quando questionados sobre a importância da utilização das planilhas eletrônicas e dos editores de texto, a maioria dos pesquisados $(55,26 \%)$ afirmaram ser muito importante e 21,05\% acreditam que estas ferramentas são razoavelmente importantes nas rotinas de trabalho.

\section{Gráfico 1. Importância das planilhas eletrônicas e do editor de texto no trabalho do contador, Tangará da Serra, 2015.}

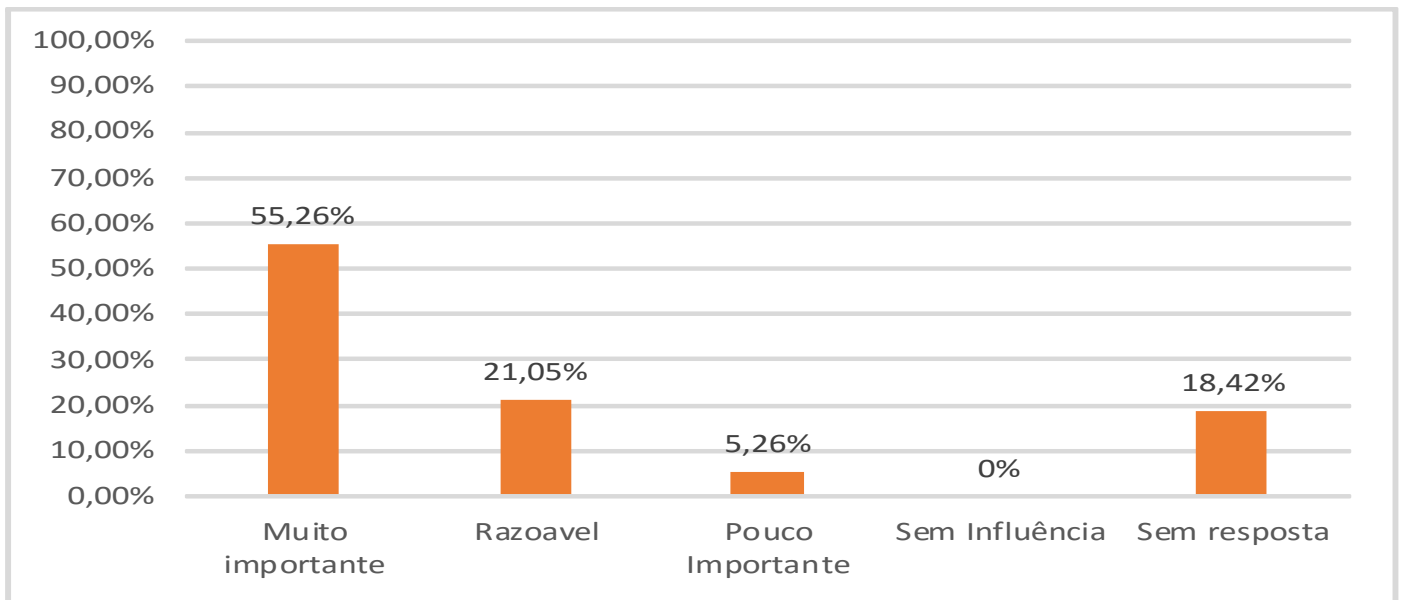

Fonte: Dados da pesquisa (2015)

A pesquisa de Silva (2008) apresenta resultados semelhantes, visto que nela 51\% dos pesquisados afirmaram que estas ferramentas são muito importantes para suas atividades. 
Percebe-se que as planilhas eletrônicas e os editores de texto são de grande importância nas atividades empresariais. Imagina-se o que seria da vida empresarial sem tais ferramentas?

Quanto à utilização de algum tipo de escrituração contábil digital pelos clientes dos escritórios/profissionais contábeis, o gráfico 2 apresenta o percentual dos clientes dos escritórios participantes da pesquisa que utilizam algum tipo de escrituração contábil digital (ECD).

Os dados mostram que em 34,21\% dos escritórios/profissionais, mais de $80 \%$ dos clientes utilizam a escrituração digital, em $10,53 \%$ os percentuais ficam na faixa de 71 a $80 \%$ e em 5,26\% na faixa de 31 a 40\%. Percebe-se que embora as ações do governo estejam voltadas para a utilização da escrituração digital, a utilização ainda não é maciça, mostrando que ainda existe a necessidade de implementação de tal ferramenta em muitas empresas.

\section{Gráfico 2. Percentual de clientes que utilizam a escrituração digital, Tangará da Serra, 2015.}

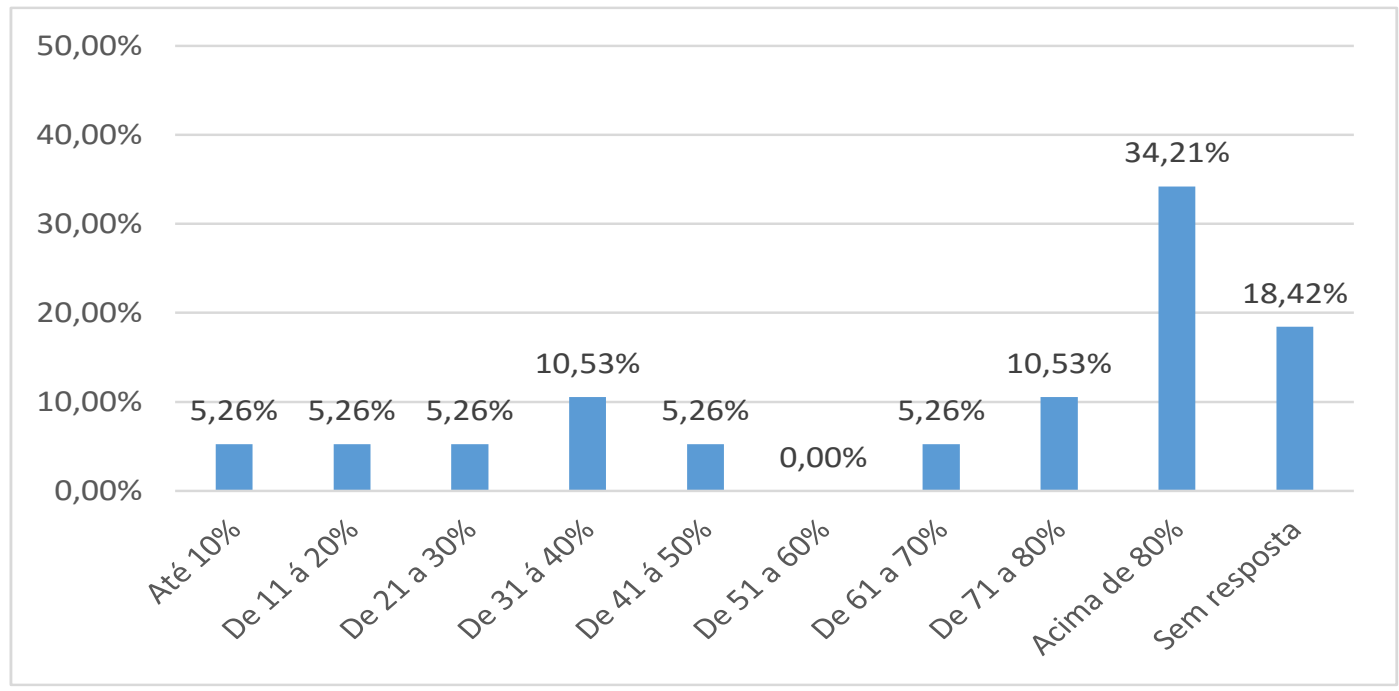

Fonte: dados da pesquisa (2015)

Quanto às maiores dificuldades enfrentadas ao trabalhar com a escrituração digital, $42,11 \%$ dos entrevistados apontaram ser a mudança constante das leis, e 10,53\% destacaram a falta de informação e a complexidade do sistema, 7,53\% dos entrevistados acreditam ser a legislação tributária intensa a principal dificuldade.

De forma contrária, quando questionados sobre as vantagens advindas com a ECD (gráfico 3), a grande maioria dos entrevistados $(68,42 \%)$ respondeu que esta trouxe maior agilidade ao trabalho. Apenas $2,63 \%$ dos profissionais acreditam que a utilização da ECD agrega maior reconhecimento ao trabalho do profissional contábil e 5,26\% não souberam responder. 
Gráfico 3. Vantagens advindas da escrituração digital para o escritório/profissionais contábil, Tangará da Serra, 2015.

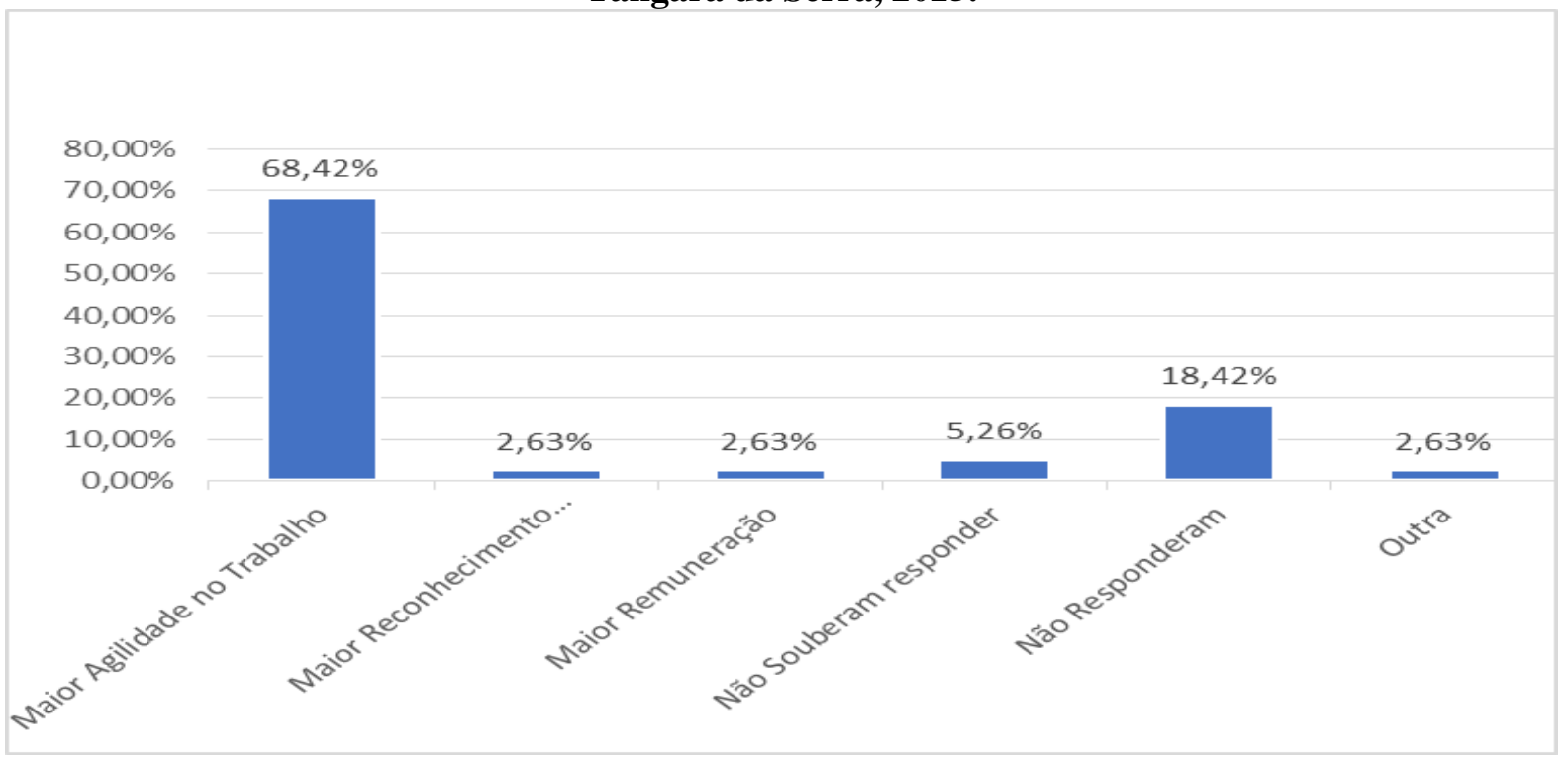

Fonte: Dados da Pesquisa ( 2015)

Aos entrevistados foi dada também a opção de apresentar outra vantagem que não estivesse colocada em questão, neste sentido um dos respondentes que representa 2,63\% respondeu que otimização do uso de papel é uma das importantes vantagens da utilização deste sistema.

De acordo com Oda (2009 apud KRUGER e SILVA, 2012), estimava-se na época que mil duzentas e cinquenta árvores deixariam de ser abatidas anualmente com a implantação do SPED, contribuindo assim com a preservação do meio ambiente .

Geralmente tudo que é novo causa certa resistência no processo de aceitação e utlização por parte das pessoas, e com a ECD não seria diferente.

Conforme o gráfico 4, para 55,26\% dos escritórios/profissionais a maioria dos clientes ainda resistem às mundanças, de modo que mesmo a ECD sendo obrigatória, muitos clientes ainda relutam em se adequarem a essas exigências. Apenas para 15,79\% a maioria dos clientes aceitam todas as exigências e em 7,89\% a maioria não conhece do assunto ou não se interessa em saber sobre os procedimentos de escrituração a que estão sujeitos e um pequeno percentual $(2,63 \%)$ ainda prefere ficar na irrregularidade. Se considerados apenas os respondentes, o percentual de escritório/profissionais em que os clientes relutam a se adequarem a ECD seria mais da metade $(67,74 \%)$. 


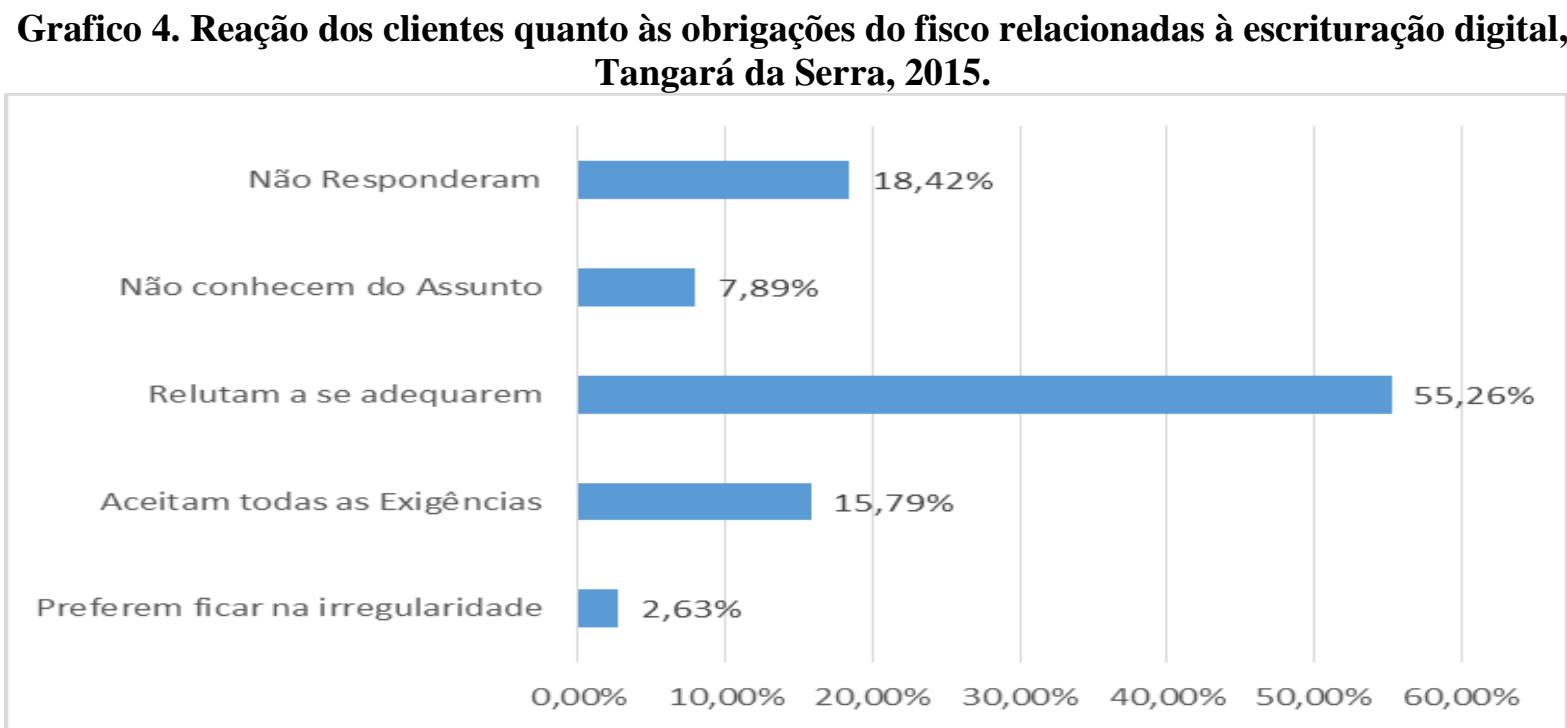

Fonte: Dados da Pesquisa ( 2015)

Vale ressaltar que existem inúmeras penalidades quanto ao não cumprimento dessas obrigações, seja no atraso ou na falta de transmissão da escrituração contábil digital, conforme estabelece a lei $\mathrm{n}^{\circ}$ 12.766, de 27 de dezembro de 2012 (BRASIL, 2012) em seu artigo $8^{\circ}$ a penalidade pela apresentação fora do prazo se sujeita as seguintes multas:

I - por apresentação extemporânea:

a) $\mathrm{R} \$ 500,00$ (quinhentos reais) por mês-calendário ou fração, relativamente às pessoas jurídicas que estiverem em início de atividade ou que sejam imunes ou isentas ou que, na última declaração apresentada, tenham apurado lucro presumido ou pelo Simples Nacional;

b) $\mathrm{R} \$ 1.500,00$ (mil e quinhentos reais) por mês-calendário ou fração, relativamente às demais pessoas jurídicas;

c) $\mathrm{R} \$ 100,00$ (cem reais) por mês-calendário ou fração, relativamente às pessoas físicas;

II - por não cumprimento à intimação da Secretaria da Receita Federal do Brasil para cumprir obrigação acessória ou para prestar esclarecimentos nos prazos estipulados pela autoridade fiscal: $\mathrm{R} \$ 500,00$ (quinhentos reais) por mês-calendário;

III - por cumprimento de obrigação acessória com informações inexatas, incompletas ou omitidas:

a) 3\% (três por cento), não inferior a $\mathrm{R} \$ 100,00$ (cem reais), do valor das transações comerciais ou das operações financeiras, próprias da pessoa jurídica ou de terceiros em 
relação aos quais seja responsável tributário, no caso de informação omitida, inexata ou incompleta);

b) $1,5 \%$ (um inteiro e cinco décimos por cento), não inferior a $\mathrm{R} \$ 50,00$ (cinquenta reais), do valor das transações comerciais ou das operações financeiras, próprias da pessoa física ou de terceiros em relação aos quais seja responsável tributário, no caso de informação omitida, inexata ou incompleta.

Em relação à redução dos custos (gráfico 5) com a utlização do SPED, a maioria dos entrevistados $(63,16 \%)$ diseram não ter ocorrido redução de gastos e apenas $18,42 \%$ responderam que houve redução de custos. Possivelmente, a diminuição do uso de papel seja um dos fatores considerados, assim como a diminuição da impressão, pois todos os arquivos são enviados por meio digital. Esse resultado não é muito diferente do apresentado pela pesquisa de Kruger e Silva ( 2012) que, embora o SPED ainda estivesse em sua fase inicial, cerca de $76 \%$ dos usuários não viam mudanças quando a redução de custos por sua utilização.

Conforme Fortes (2009) o setor contábil vive a era digital e cabe aos profissionais que estão no mercado de adaptarem a esta nova realidade para assim desempenhar da melhor forma possível sua função, fazendo face aos novos desafios advindos da escrituração digital.

\section{Grafico 5. Redução dos custos na atividade contábil com a utilização do SPED, Tangará da Serra, 2015.}

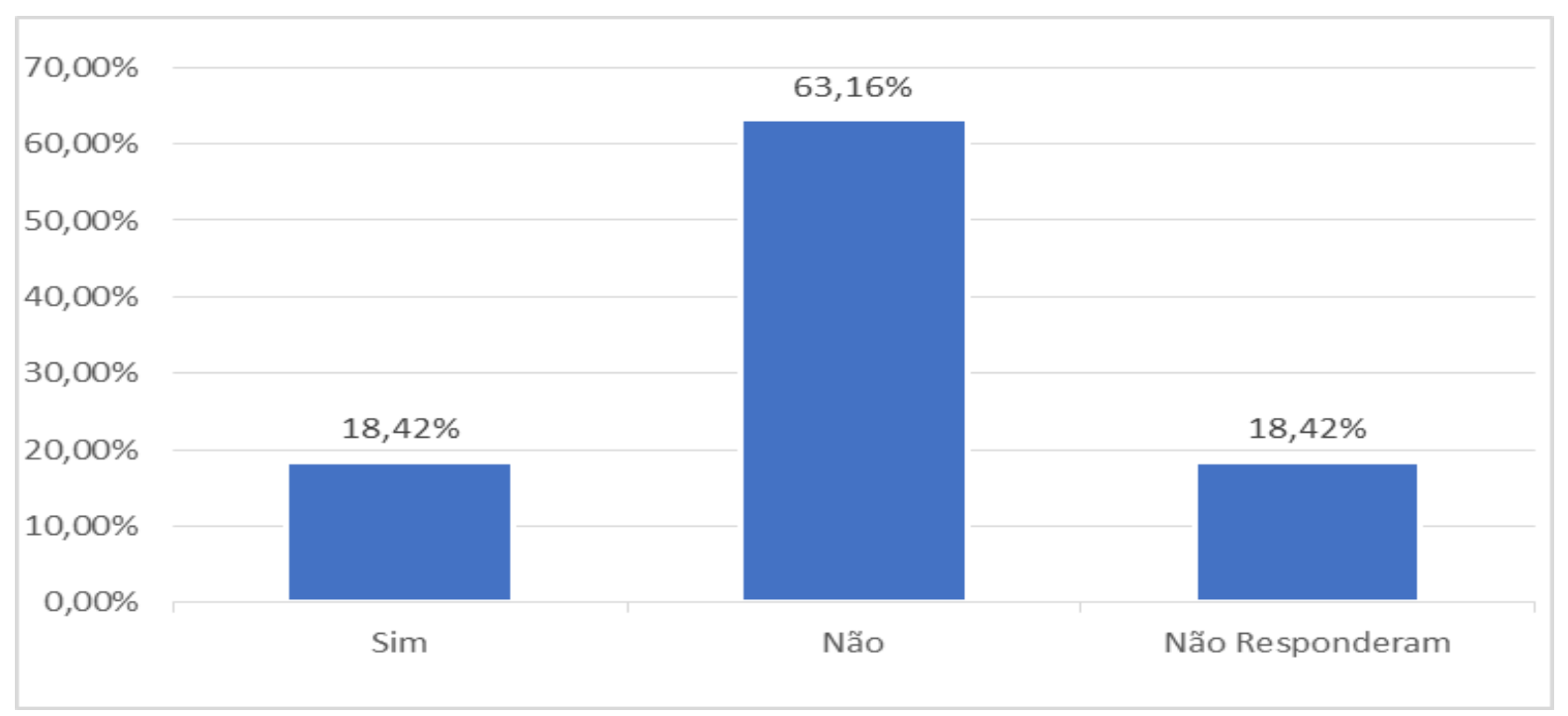

Fonte: Dados da Pesquisa ( 2015)

Diante disso, quando questionados sobre a implantação do SPED, se os profissionais participaram de cursos e workshops para se adequarem, 47,37\% disseram que participaram de 
diversos cursos, $21,05 \%$ afirmaram ter participado de poucos e 13,16\% não participaram de nenhum curso, o percentual de entrevistados que não responderam foi de 18,42\%.

A respeito da influência do SPED no mercado de trabalho para o profissional contabil, $44,74 \%$ disseram ser a qualificação dos profissionais, visto que constantemente surgem novas exigências e mudanças no sistema, forçando os profissionais a se qualificarem periodicamente. Um pequeno percentual $(15,79 \%)$ respondeu que por agilizar o processo de escrituração, o SPED permite ao profissional empregar mais tempo para as atividades de auxilio à gestão.

Quanto à retirada do mercado daqueles profissionais que apenas emitem guias de recolhimento de tributos e a influência do SPED na melhor remuneração e valorização dos profissionais, apenas 7,89\% respectivamente escolheram estas alternativas de resposta. A opção outra resposta foi escolhida por $5,26 \%$, no entanto, não foi especificada qual seria a outra opção. O percentual dos que não responderam foi de $18,42 \%$.

Para Manoel et al. (2011) com a implantação e expansão do SPED surge a busca por novos sistemas e tecnologias mais aprimorados a fim de auxiliar no processo de escrituração, uma vez que ao profissional contábil será essencial conhecer a realidade de seus clientes para transmitir as informações reais a fim evitar transtornos futuros .

Quanto às contribuições trazidas pelo SPED, para 44,74\% foi diminuição do risco de fraudes, para 28,95\% a simplificação no cumprimento de obrigações acessórias e para 2,63\% a redução dos erros na emissão de notas fiscais .

Grafico 6. Contribuições trazidas pela implantação do SPED, Tangará da Serra, 2015.

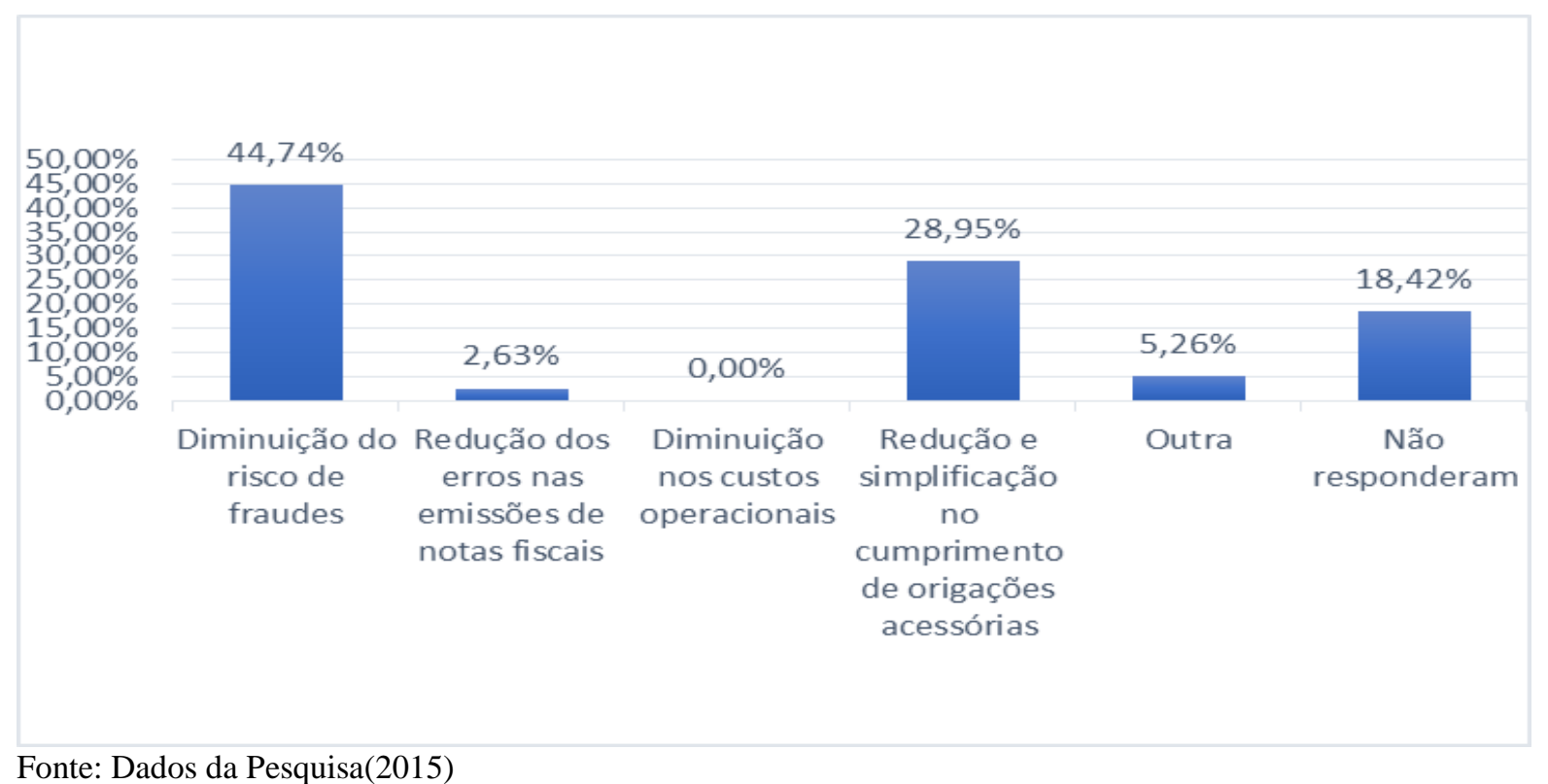

Fonte: Dados da Pesquisa(2015) 
De acordo com a Receita Federal do Brasil, dentre os muitos benefícios atribuídos ao SPED destacam-se: proporcionar condições de maior competitividade às empresas, isso porque através dele acredita-se que o risco de fraudes e omissões de informações é reduzido, gerando uma concorrencia mais leal (BRASIL,2015).

\section{Gráfico 7. Acreditam que o SPED proporciona condições de maior competitividade,} Tangará da Serra, 2015.

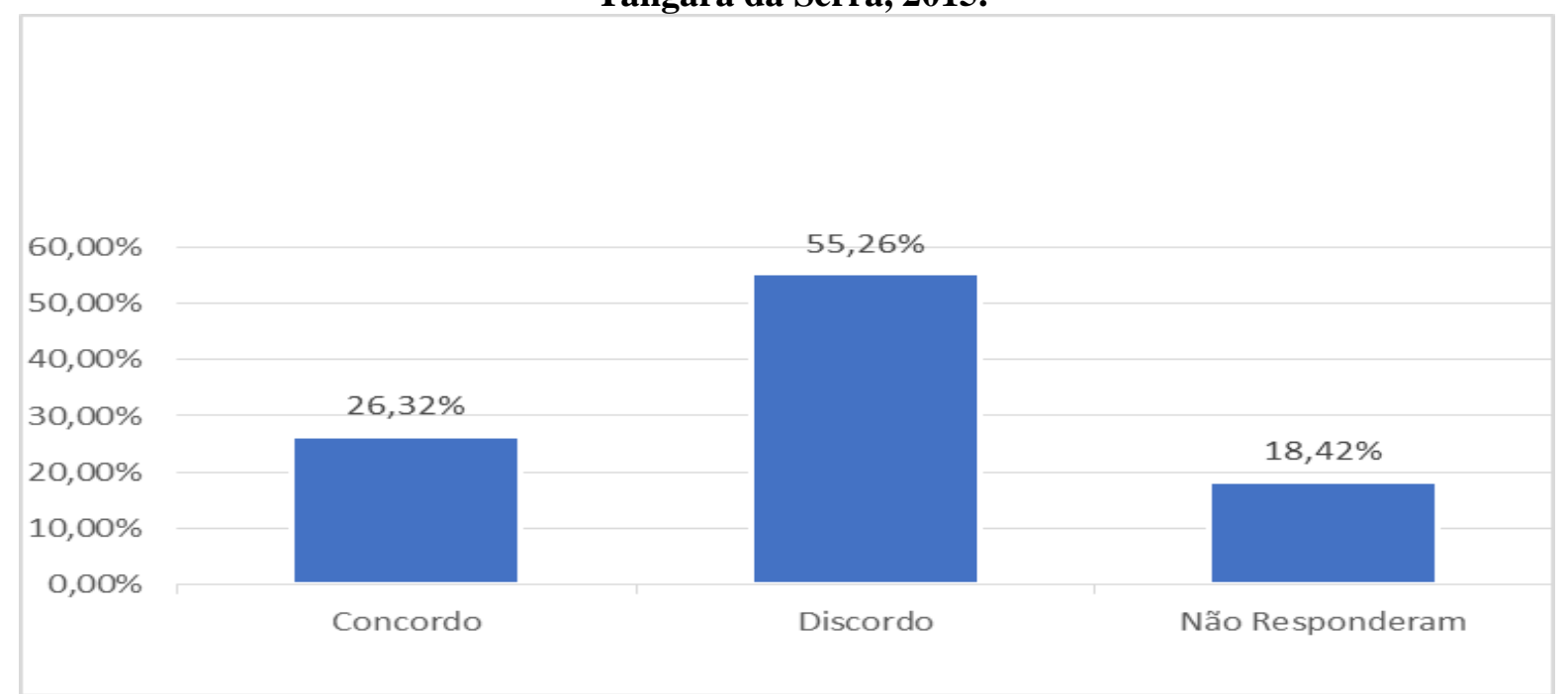

Fonte: Dados da Pesquisa (2015)

Os entrevistados foram questionados sobre essa afirmação, de modo que 55,26\% responderam (gráfico 7) não concordar com a afirmativa e 26,32\% concordaram. Se considerados apenas o total de questionarios respondidos, o percentual de entrevistados que não concordam chegaria a $67,74 \%$.

\section{CONSIDERAÇÕES FINAIS}

Os resultados desta pesquisa evidenciaram a importância da adequação das empresas às novas exigências impostas pelo fisco, o qual, utilizando-se dos mecanismos advindos da evolução tecnológica, criou o Sistema Público de Escrituração Digital a fim reduzir o risco de fraudes, índice de sonegação de impostos e potencializando a transparência das empresas.

A pesquisa alcançou os objetivos propostos uma vez que identificou com base na opinião dos profissionais contábeis do municipio os impactos da tecnologia da informação na escrituração contábil. Os dados mostraram que todos os escritórios/profissionais contábeis, que responderam o questionário (100\%), utilizam algum tipo de software contábil e que em $44,74 \%$ deles mais de $70 \%$ dos clientes já utilizam algum tipo de escrituração digital. No 
entanto, ainda é muito expressivo o percentual de clientes que relutam em se adequar às exigencias do governo, ou seja, 66,74\%, quando considerados apenas os respondentes.

Assim, é interessante que os profissionais da área busquem meios de concientização para que seus clientes estejam atentos quanto à essencialidade do cumprimento das leis. Os principais argumentos podem ser as vantagens advindas da utilização da escrituração digital, das quais pode-se destacar a otimização do tempo e a maior agilidade na geração de relatórios, gerando maior disponibilidade para o profissional contábil contribuir com a empresa no processo de gestão e tomada de decisões.

Os profissionais que trabalham com a escrituração digital em sua maioria $(63,16 \%)$ não apontam a redução dos custos da atividade em decorrência da adoção da tecnologia da informação. No entanto, mesmo que não muito expressivo a ponto de não ser tão perceptível, a redução existe, principalmente em função da redução no consumo de papel e nos gastos com impressão. Além disso, destaca-se a otimização do tempo, pois libera o profissional para desenvolver outras atividades que talvez necessitassem de contratação de mais profissionais para desempenhá-las, caso os processos tivessem que ser todos manuais como por exemplo o arquivo e controle de livros de entrada e saida que hoje são todos eletrônicos.

Conclui-se que o SPED e a ECD são ferramentas que trouxeram desafios aos profissionais, exigindo mais qualificação, em virtude da integração direta com o fisco, gerando maior responsabilidade. Através delas também aumentou a responsabilidade do contribuinte, que é cobrado pelos profissionais a transmitir diariamente ao seu contador todos os fatos ocorridos em sua empresa, possibilitando a redução das fraudes, sonegação e possivelmente até mesmo a concorrencia desleal.

\section{REFERÊNCIAS}

BAZZOTTI, C.; GARCIA, E. A importância do sistema de informação gerencial. Ciências Sociais Aplicadas em Revista, v, 6, n 11, p, 2006. Disponível em:

<http://e-revista.unioeste.br/index.php/csaemrevista/article/view/368> Acesso em 15 de Abril de 2015.

BRASIL. Decreto $\mathbf{n}^{0}$ 6.022 de 22 de janeiro de 2007. Institui o Sistema Público de escrituração Digital - Sped. Disponível em:

<http://www.planalto.gov.br/ccivil_03/_Ato2007-2010/2007/Decreto/D6022.HTM>Acesso: em 03 de Abril de 2015.

BRASIL. RECEITA FEDERAL DO BRASIL. Sped Sistema Público de Escrituração Digital 2012. Disponível em: <http://www1.receita.fazenda.gov.br/sistemas/spedcontabil/como-funciona.htm> Acesso em: 05 de maio de 2015. 
BRASIL. Lei $\mathrm{n}^{\circ} 12.766$ de 27 de Dezembro de 2012. Institui normas gerais para licitação e contratação de parceria público-privada no âmbito da administração pública, para dispor sobre o aporte de recursos em favor do parceiro privado, 10.637 , de 30 de dezembro de 2002. Disponível em: <http://www.planalto.gov.br/ccivil_03/_ato20112014/2012/Lei/L12766.htm> Acesso em 27 de agosto de 2015.

BRASIL. RECEITA FEDERAL DO BRASIL. Sped Sistema Público de Escrituração

Digital 2015. Disponível em: < http://www1.receita.fazenda.gov.br/sistemas/sped-

contabil/legislacao.htm > Acesso em: 05 de maio de 2015.

BEUREN, I. M. Como Elaborar Trabalhos Monográficos em Contabilidade. $3^{\text {a }}$. ed. São Paulo: Atlas,2003.

CORNACHIONE Jr., E. B. Informática aplicada às áreas de contabilidade, administração e economia. 3. ed. São Paulo: Atlas, 2001.

CORDEIRO, J. S.; DUARTE, A. M. P. O profissional Contábil diante da nova realidade. Qualit@s, V.01, No 01, 2006.

COTRIN, A.M.; SANTOS, A.L.; JUNIOR, L.Z. A evolução da contabilidade e o mercado de trabalho para o contabilista. Revista Conteúdo, $\mathrm{n}$ 2, 2012. Disponível em: http://www.conteudo.org.br/index.php/conteudo/article/view/70Acesso em 13 de abril de 2015.

CRUZ, T. Sistemas de informações gerenciais - tecnologia da informação e a empresa do século XXI. $2^{a}$ ed., São Paulo: Atlas, 2000.

DUARTE, R. D. As diretrizes do Gestor eficaz. Exame. São Paulo, p 43, 30 jul.2011.

FORTES, J.C. Desafios e Perspectivas da Profissão Contábil 2009. Disponível em:

$<$ http://www.classecontabil.com.br/artigos/desafios-e-perspectivas-para-a-profissaocontabil?tmpl=print > Acesso em:13 de Março de 2015.

GIL, A. L. Sistemas de Informações Contábil/Financeiros. $3^{\text {a }}$ ed. Atlas, 1999.

IBGE. Instituto Brasileiro de Geografia e Estatística. Diretoria de Pesquisas, Coordenação de População e Indicadores Sociais 2014. Disponível em:

<http://www.cidades.ibge.gov.br/xtras/perfil.php?> Acesso em 08 de maio de 2015.

MANOEL, V. et al. Escrituração Digital: Consequências, Benefícios e a Evolução da Profissão Contábil, 2011. Disponível em: $<$ https://www.inesul.edu.br/revista/arquivos/arqidvol_15_1321048316.pdf> Acesso em 27 de julho de 2015.

MANZATO, A. J.; SANTOS, A. B. S. A elaboração de questionário na pesquisa quantitativa, [2012]. Disponível em: http://www.inf.ufsc.br/ verav/Ensino_2012_1/ELABORACAO_QUESTIONARIOS_PESQU ISA_QUANTITATIVA.pdf . Acesso em 23 de maio de 2016.

MARION, J. C. Contabilidade Empresarial. 11. Ed.- São Paulo: Atlas, 2005.

MARION, J. C. Contabilidade Básica. 8.ed. São Paulo - SP: Atlas, 2006.

MARTINS, P. L. et al. O profissional Contábil na era da informação.. Anais do $9^{\circ}$ Simpósio de excelência em Gestão e Tecnologia da UFSJ. Minas Gerais, 2012. Disponível em:

$<$ http://www.aedb.br/seget/arquivos/artigos12/28816544.pdf > Acesso em 06 de julho de 2015.

NEVES JUNIOR, I. J. ; OLIVEIRA, C. M.; CARNEIRO, E. E. Estudo exploratório sobre os benefícios e desafios da implantação e utilização do Sistema Público de Escrituração Digital SPED na opinião de prestadores de serviços contábeis no Distrito Federal. Anais do $\mathbf{8}^{\mathbf{o}}$ 
Congresso USP de Iniciação Científica em Contabilidade. São Paulo, 2011. Disponível em $<$ http://www.congressousp.fipecafi.org/web/artigos112011/564.pdf.>Acesso em 28/05/2015.

NÚCLEO DE ENSINO E PESQUISA EM CONTABILIDADE (NEPEC). Perfil sócio econômico de Tangará da Serra 2011/2012. Tangará da Serra, 2012. Disponível em: http://www2.unemat.br/nepec/perfil_tangara/economia.html. Acesso em 20 de outubro de 2015.

OLIVEIRA. L. M. et al. Manual de Contabilidade Tributaria. $13^{\circ}$ ed. São Paulo: Atlas, 2014.

OLIVEIRA, F. M.; PRADO, C. A. S.; MORAES, L S. Sistema Público de Escrituração Digital- SPED: Uma análise sobre o processo e operacionalização da Nota fiscal Eletrônica "NFE" nos supermercados no município de Barreira-BA. Disponível em: $<$ http://semanaacademica.org.br/system/files/artigos/artigofabricio.pdf >: Acesso em:18 de março de 2015.

OLIVEIRA, D. P. R. de. Sistemas, organizações e métodos: uma abordagem gerencial. 13. ed. São Paulo, 2002.

PADOVEZE, C. L. Contabilidade Gerencial: um enfoque em sistemas de informação contábil. São Paulo: Atlas, 1997.

PADOVEZE, C. L. Contabilidade Gerencial: um enfoque em sistema de informação contábil. 7ª Edição. São Paulo: Atlas, 2010.

PADOVEZE, C. L. Sistemas de informações contábeis. 2. ed. São Paulo: Atlas, 2000.

PADOVEZE, C. L. Sistemas de informações contábeis: fundamentos e análise. $4^{\mathrm{a}}$ ed. São Paulo: Atlas, 2004.

PADOVEZE, C. L. Sistemas de Informações Contábeis. São Paulo: Atlas, 2009.

RUSCHEL, M. E; FREZZA, R; UTZIG, M.J.S. O impacto do SPED na contabilidade desafios e perspectivas do profissional contábil. Revista Catarinense de Ciência Contábil, v 10, n 29, 2011.

SÁ, A. L. História geral e das doutrinas da contabilidade. São Paulo: Atlas, 1997.

SÁ, A.L. A Evolução da Contabilidade. São Paulo: Thomson, 2006.

SILVA, P.O.C.; KRUGER, C. O papel do contador frente às novas tecnologias da escrituração contábil com as empresas 2012. Disponível em: $<$ http://www.eumed.net/cursecon/ecolat/br/13/contabilidad.html> Acesso em 14 de março de 2015.

SILVA, J. M. M. A. F. R. O uso da tecnologia na profissão contábil: Uma abordagem ao SPED e Nota Fiscal Eletrônica. Rio de Janeiro, 2008. Disponível em:

<http://www.jmrconsultoria.com.br/pdf/artigo_sped_nota_fiscal_eletronica.pdf $>$. Acesso dia 28 de Maio de 2015.

SOUZA, A. A; PASSOLONGO. C. Avaliação de Sistemas de Informações Contábeis: Estudo de Casos Múltiplos. Revista Contabilidade, Gestão e Governança, v 8, n 2, 2005. Disponível em: <http://www.cgg-amg.unb.br/index.php/contabil/article/view/165>Acesso em 24 de abril de 2015. 